\title{
Eothalassius, a new genus of parathalassiine flies (Diptera: Empidoidea: Dolichopodidae) from Southeast Asia and Papua New Guinea
}

\author{
IGOR V. SHAMSHEV ${ }^{1}$ and PATRICK GROOTAERT ${ }^{2}$ \\ ${ }^{1}$ All-Russian Institute of Plant Protection, Shosse Podbel'skogo 3, 188620 St. Petersburg - Pushkin, Russia; \\ e-mail: shamshev@mail.ru \\ ${ }^{2}$ Department of Entomology, Royal Belgian Institute of Natural Sciences, Rue Vautier 29, B-1000 Brussels, Belgium; \\ e-mail: Patrick.Grootaert@naturalsciences.be
}

\begin{abstract}
Key words. Taxonomy, Diptera, Empidoidea, Dolichopodidae, Parathalassiinae, Eothalassius, new genus, new species, Oriental
\end{abstract} region

\begin{abstract}
A new genus of parathalassiine-like flies, Eothalassius gen. n., and two new species, Eothalassius platypalpus sp. n. (type species), E. gracilis sp. n., are described from the coasts of Southeast Asia and Papua New Guinea. The phylogenetic relationships of the new genus with other genera assigned to Parathalassiinae and Dolichopodidae are discussed.
\end{abstract}

\section{INTRODUCTION}

The representatives of the genera joined currently in the subfamily (or tribe by authors) Parathalassiinae (Cumming \& Brooks, 2002; Ulrich, 2003) are mainly very small and rarely collected flies. They inhabit specific biotopes of a narrow zone of sea coasts or river banks, including wet and dry parts of sandy beaches, dunes with sparse vegetation and wet stones. The subfamily includes six extant genera: Parathalassius Mik, 1891 (6 species), Microphorella Becker, 1909 (16 species), Plesiothalassius Ulrich, 1991 (2 species), Amphithalassius Ulrich, 1991 (2 species), Thalassophorus Saigusa, 1986 (1 species) and Chimerothalassius Shamshev \& Grootaert, 2003 (1 species) (Smith, 1972; Saigusa, 1986; Chvála, 1988; Ulrich, 1991; Gatt, 2003; Shamshev, 2003; Shamshev \& Grootaert, 2003, 2004). Additionally, four genera (Cretomicrophorus Negrobov, 1978; Archichrysotus Negrobov, 1978; Retinitus Negrobov, 1978; Electrophorella Cumming \& Brooks, 2002) described from Cretaceous and Baltic ambers were also assigned to this group (Negrobov, 1978; Evenhuis, 1994; Grimaldi \& Cumming, 1999; Cumming \& Brooks, 2002).

Within Empidoidea, this group of genera, together with Microphor Macquart, 1827, Schistostoma Becker, 1902, Microphorites Hennig, 1971 and Avenaphora Grimaldi \& Cumming, 1999, forms a monophyletic lineage with Dolichopodidae (Colless, 1963; Hennig, 1970, 1971; Chvála, 1981, 1983; Yeates \& Wiegmann, 1999; Collins \& Wiegmann, 2002). However, the relationships within the lineage are not quite clear yet (Ulrich, 1991; Cumming \& Brooks, 2002). The taxonomic status of this group of genera is also a subject of controversies. They were united into a separate family Microphoridae, including subfamilies Microphorinae and Parathalassiinae (Chvála, 1983) or were discussed within Dolichopodidae (Cum- ming \& Sinclair, 2000; Ulrich, 2003). So, any new findings of unknown representatives of this group would be of particular interest.

Intensive collections along the coasts of Southeast Asia and Papua New Guinea allowed us to obtain new materials on Parathalassiinae. The present paper contains the description of a new genus including two new species of the subfamily. Additionally, the phylogenetic relationships of the new genus are shortly discussed.

Very little is known about the biology and distribution of Parathalassiinae, including the new genus. Parathalassius is only known after a few localities in the Holarctic, including sandy (usually wet beaches) coasts of the Mediterranean and the Pacific Ocean (Chvála, 1988; Shamshev, 1998). Microphorella has a similar distribution pattern in the Holarctic, one species occurring in Australia, and four species known in Southeast Asia. Microphorella is the only group of the subfamily that is found near fresh-water reservoirs, although some species were collected near the sea shore (Melander, 1928; Chvála, 1983, 1988; Gatt, 2003; Shamshev, 2003; Shamshev \& Grootaert, 2004). Plesiothalassius and Amphithalassius are only known from the coasts of the Indian and Atlantic Oceans in South Africa (Smith, 1972; Ulrich, 1991). Thalassophorus was collected on wet stones in a rocky beach in north of Hokkaido (Saigusa, 1986). Chimerothalassius is known from stony beaches in New Zealand (Shamshev \& Grootaert, 2003).

\section{MATERIAL AND METHODS}

This study is based on Diptera materials housed in the Entomology Department of the Royal Belgian Institute of Natural Sciences, Brussels (RBINS). The flies were collected by sweeping or in white pan traps (Pollet \& Grootaert, 1987) and transferred to $75 \%$ ethanol. Terms used for adult structures primarily follow those of McAlpine (1981), although the termi-

* Present address: Department of Entomology, Royal Belgian Institute of Natural Sciences, Rue Vautier 29, B-1000 Brussels, Belgium. 
nology for the antenna is taken from Stuckenberg (1999). Homologies for the male terminalia follow Sinclair (2000). To facilitate observations, some parts of the body were macerated in hot $10 \% \mathrm{KOH}$ or $85 \%$ lactic acid and immersed in glycerine. Drawings of morphological features were made with a camera lucida attached to a compound microscope.

In describing the hypopygium, "dorsal" and "ventral" refer to position prior to genital rotation and flexion. Figures showing the male genitalia in lateral view are oriented as they appear on the intact specimen (rotated and lateroflexed to the right). Due to inconspicuous setation of these very small flies the term "bristle" is mainly used for differentiated large setae on the head, mesonotum, and legs bearing a particular name or one of a series with a particular name (e.g. notopleural bristle, dorsocentral bristle, ocellar bristle).

\section{Eothalassius gen. $n$.}

TYPE SPECIES: Eothalassius platypalpus sp. n.

Etymology: (Greek) $\varepsilon \omega \varsigma=$ southern, $\theta \alpha \lambda \alpha \tau \tau \alpha$, sea, and $\theta \alpha \lambda \alpha \sigma \sigma 1 \mathrm{~s}$, belonging to the sea.

Gender. Masculine.

Diagnosis. Distinguished from related extant (Parathalassius, Microphorella, Plesiothalassius, Amphithalassius, Thalassophorus) and fossil (Cretomicrophorus, Archichrysotus, Retinitus, Electrophorella) genera by the following combination of characters: face very narrow in both sexes, postpedicel very small, style at least five times as long as postpedicel; prosternum fused with proepisternum; wings narrow, anal lobe greatly reduced, costa circumambient, with one row of spinules on anterior margin, vein $\mathrm{R}_{1}$ ending before midpoint of wing, vein $\mathrm{CuA}_{2}$ reflexed; male abdominal segments 5-8 modified, hypandrium largely fused with epandrium; female oviscapt with setose tergite 10 and slender cerci.

Description. Head broader than thorax in dorsal view, broad oval in lateral view, nearly 1.5 times higher than wide. Occiput more or less rounded, with upper median part moderately to strongly concave; insertion of neck high on head. Eyes dichoptic in both sexes, entirely covered with distinct uniform ommatrichia, with inner margins not emarginate near antennae; ommatidia large, uniform. Face very narrow (sometimes almost linear) in the middle, slightly widened both above and below. Clypeus very small, somewhat produced below, convex, not separated from upper face, rounded apically. Genae very narrow. Frons broadly triangularly widening above in both sexes. Ocellar triangle weakly prominent, subdorsal. Bristles of head well-developed: two inclinate anterior frontal-orbitals, two lateroclinate posterior frontal-orbitals, two lateroclinate anterior ocellars, at least two minute lateroclinate posterior ocellars, two lateroclinate outer-verticals and two inclinate inner-verticals. Postocular occipital bristles short, arranged in one or 2-3 rows in upper part; few setulae present just behind mouthopening including postgena. Antenna inserted above middle of head in profile. Scape very short, cup-shaped, bare; pedicel larger than scape, subglobular, ringed with circlet of short setae; postpedicel broad or short oval; microsetulose in apical part. Style apical, arista-like, 1-segmented, at least five times longer than postpedicel, whip-like in apical part, mostly microsetulose (except almost bare basal part), with setulae in apical part longer than width of aristal trunk, bearing sensory pit in subbasal part, lacking secondary sexual adornments. Proboscis short, well visible, pointing downward. Palpus large, flattened, with secondary sexual differences, lacking basal sensory pit. Details of mouthparts as in Figs 7-9. Labellum well developed, moderately large, produced into small lobe at apex. Six geminate inconspicuous pseudotracheae present, with walls weakly sclerotised. Stipes long, slender; lacinia absent. Labrum heavily sclerotised, convex basally, with pointed apex; epipharynx with slender ventral projection, bearing subapical spinules; epipharyngeal carina elongate; epipharyngeal blades slender; hypopharynx slender, almost straight; prementum with 3-4 short setae on each side; clypeal ridge rather short, shorter than cibarium.

Thorax with scutum moderately arched, prescutellar depression hardly prominent. Prosternum fused with proepisternum. Lateral lobe of antepronotum below postpronotal lobe and proepisternum with one minute setula (sometimes lacking). Postpronotal lobe with 1 very short bristle (additionally, few minute setulae sometimes present). Mesonotal bristles well-differentiated: one presutural supra-alar (inserted far from postpronotal lobe, often inclinate and nearly as long as notopleural bristles), 0-1 postsutural supra-alar, two notopleurals, one short postalar and two very long cruciate scutellars (longest among mesonotal bristles); additionally, one row of 4-6 supraalar setulae present. Dorsocentrals 1-serial, three to about 6-7 per row, with or without accessory setulae. Acrostichals minute, few in number, arranged in two irregular rows or lacking; upper part of vertical anterior surface of scutum with one pair of setulae. Mesopleuron bare.

Wing (Figs 12, 13, 25) narrow, 3.0-4.0 times longer than wide; with anal lobe weakly developed; entirely covered with minute microtrichia (including veins); alula absent. Basal section of costa with 3-4 bristles becoming longer distad; additionally, costa bearing short spine like bristles and fine hairs along anterior margin and mostly ciliate along posterior margin (bare near wing base). Pterostigma (or stigmatic sclerotisation) lacking. Costa circumambient but strong only along anterior margin up to short distance beyond apex of $\mathrm{R}_{4+5}$, evanescent along hind margin. All longitudinal veins complete, distinctly reaching wing margin. Sc very close to $R_{1}$, reduced to fold in its apical section, ending in costa. Rs in basal $1 / 5$ of wing, with 2 branches. $\mathrm{R}_{1}$ not thickened, short, joining costa before midpoint of wing, somewhat arcuate. $\mathrm{R}_{2+3}$ more or less straight, ending nearer to wing apex. $R_{2+3}$ and $\mathrm{R}_{4+5}$ almost parallel near wing-apex. $\mathrm{R}_{4+5}$ unforked, ending near wing-tip. $\mathrm{R}_{4+5}$ and $\mathrm{M}_{1}$ somewhat diverging near wing-apex. Base of $\mathrm{M}_{1}-\mathrm{M}_{2}$ about at midpoint of wing. Distance between apices of $\mathrm{M}_{1}$ and $\mathrm{M}_{2}$ longer than distance between apices of $\mathrm{M}_{2}$ and $\mathrm{CuA}_{1}$. $\mathrm{CuA}$ reflexed. $A_{1}$ absent. $A_{2}$ present on posterobasal margin of wing. Crossvein $\mathrm{h}$ almost opposite to base of Rs. Short $\mathrm{r}-\mathrm{m}$ crossvein present, in basal $1 / 5$ of wing, perpendicular to longitudinal veins. Crossvein bm-cu incomplete. Cell dm absent (dm-cu vein absent) or present. Cells br, bm and 

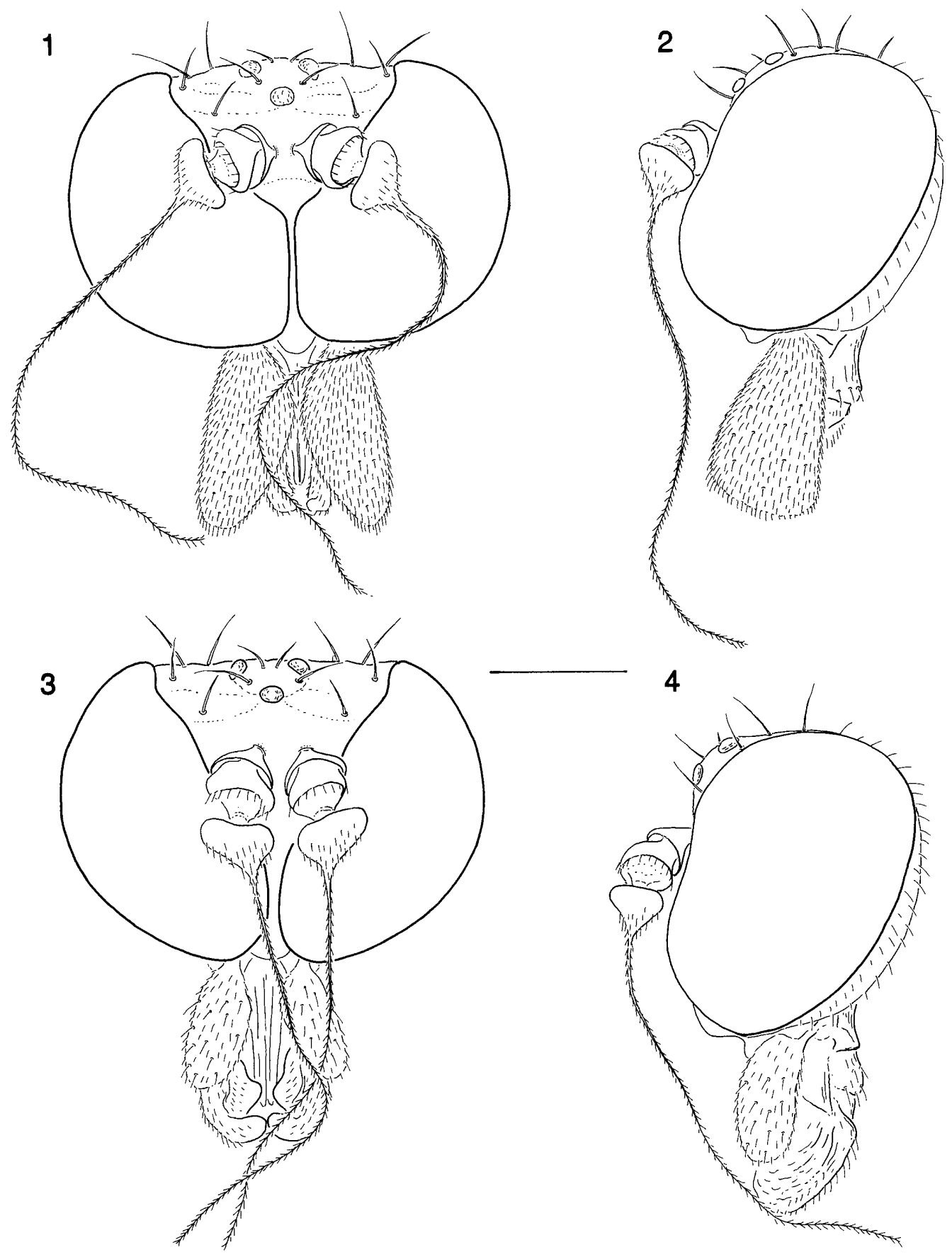

Figs 1-4. Eothalassius platypalpus sp. n. 1 - male head, anterior view; 2 - the same, lateral view; 3 - female head, anterior view; 4 - the same, lateral view. Scale: $0.1 \mathrm{~mm}$.

cup in basal $1 / 5$ of wing. Cell br slender, longer than cells bm and cup. Cells bm and cup subequal in length and width, both somewhat broader than cell br. Cell cup with proximal end acutely rounded.

Legs moderately long, slender, unmodified and without secondary sexual differences, clothed with short mostly inconspicuous setae. Tarsal claws, pulvilli and setiform empodium well developed on all legs,

Abdomen rather short and broad, with scattered short setation, lacking conspicuous posteromarginal setae. Abdominal muscle plaques present, distinct. Male seg- ments 1-4 symmetrical with simple sternites and tergites, forming preabdomen. Postabdomen spirally contorted, segments 5-7 confined to left side forming cavity to place hypopygium; sternite 5 indented at hind margin to form anterior border of groove concealing tip of hypopygium; tergites and sternites 6 and 7 with more strongly sclerotised right margins. Tergite 7 lacking setation. Sternite 8 moderately large, subrectangular, lying at hind end exposed posterolaterad; tergite 8 vestigial.

Male terminalia lateroflexed to the right, inverted and with caudal pole directed forward, rather small, asymmet- 


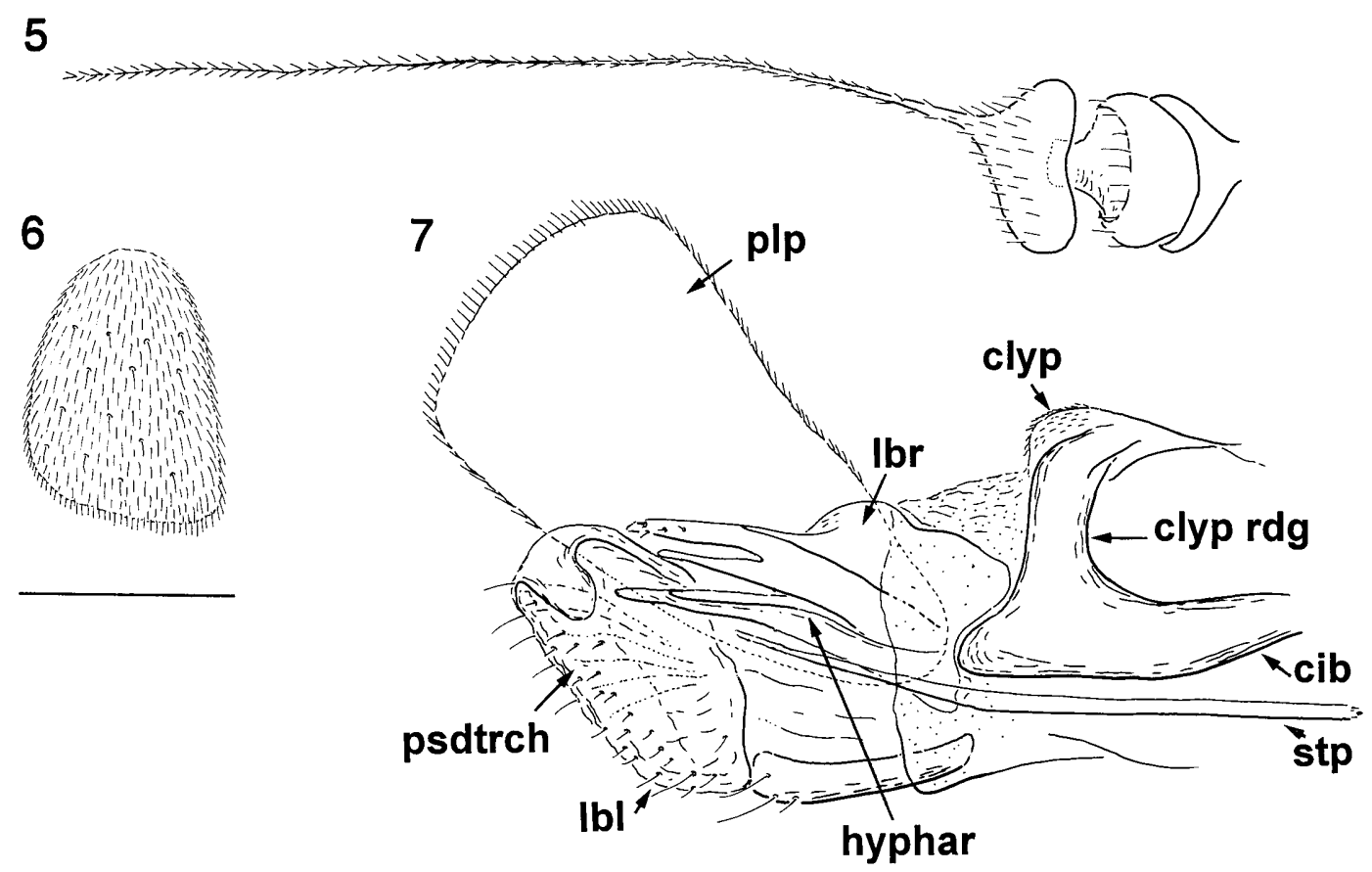

8

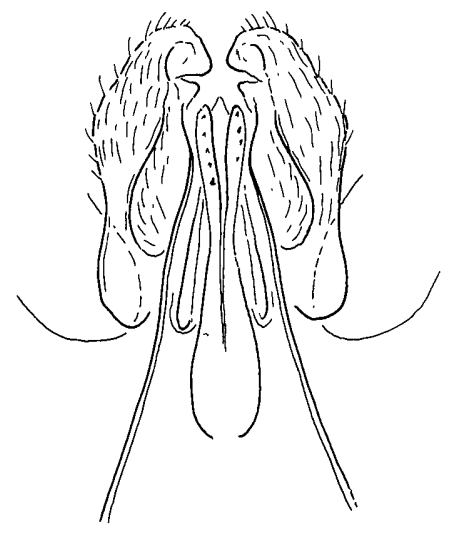

9

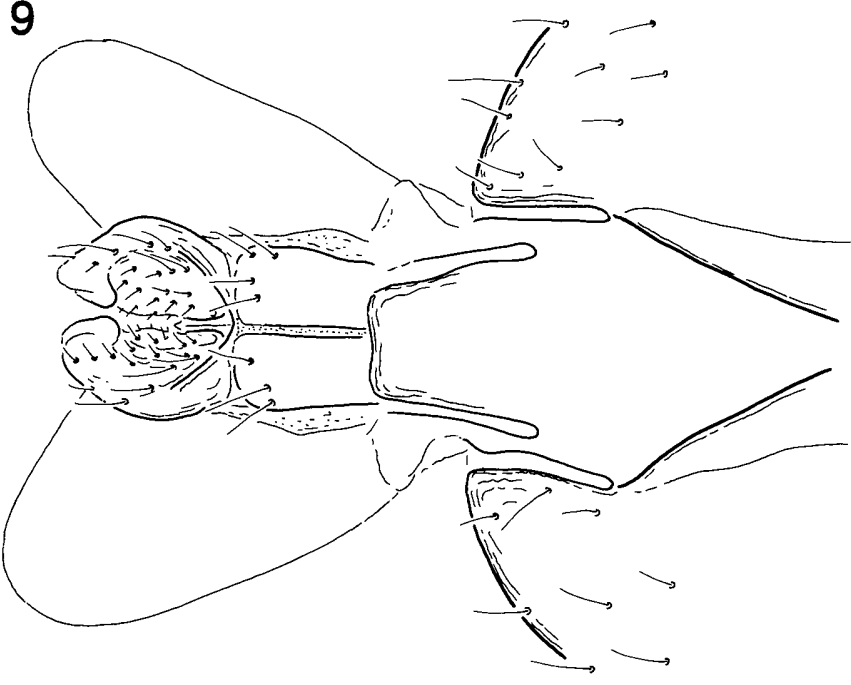

Figs 5-9. Eothalassius platypalpus sp. n. 5 - male antenna, dorsal view; 6 - male palpus, dorsal view; 7 - mouthparts, lateral view; 8 - the same, ventral view; 9 - the same, dorsal view. cib - cibarium; clyp - clypeus; clyp rdg - clypeal ridge; hyphar hypopharynx; lbl - labellum; lbr - labrum; plp - palpus; psdtrch - pseudotrachea; stp - stipes. Scale: $0.1 \mathrm{~mm}$.

rical, shorter than apical half of abdomen. Hypandrium large, mostly fused with epandrium, concave at apex. Epandrium with well-developed ventral projections; surstyli of complicated structure, with an additional internal process. Cerci weakly sclerotised, large. Postgonites present, large, of complicated structure, "leaf-like" in apical part. Phallus tubular, more or less smoothly arcuate, ejaculatory apodeme subrectangular.

Female abdomen more or less gradually tapering, segments 1-6 forming preabdomen into which posterior segments are retracted and only partly visible; postabdomen rather slender, mostly covered with scattered setulae, sternite 8 articulated with tergite 8 posteriorly; tergite 8 paired; tergite 10 and sternite 10 articulated; hemitergites 10 moderately large, with three long bristles each. Cerci slender, weakly sclerotised, bearing one very long bristle in apex and few short setulae. Spermatheca (Fig. 21) visible as darkened spot near tergite 5, tubular. Spermathecal receptacle spherical, weakly sclerotised.

Remarks. Eothalassius is most similar to the genera Microphorella and Electrophorella. However, Microphorella has shorter antennal style, longer vein $\mathrm{R}_{1}$ and hypandrium separated from epandrium. Electrophorella can be readily distinguished from Eothalassius in the absence of the anterior portion of crossvein m-cu (base of vein $\mathrm{M}_{2}$ ). 


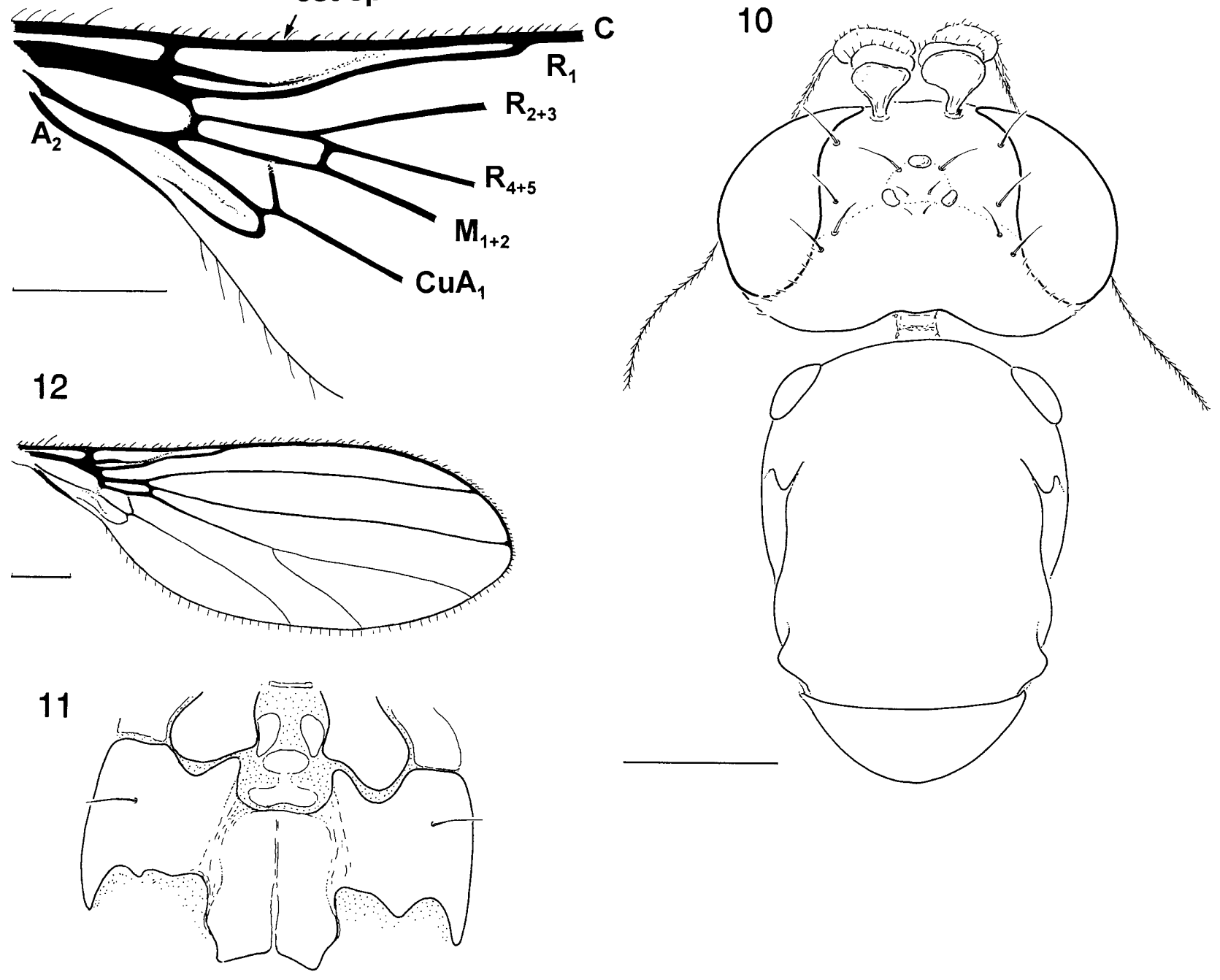

Figs 10-13. Eothalassius platypalpus sp. n. 10 - head and thorax, dorsal view; 11 - prothoracic pleurosternal region, anterior view; 12 - wing, dorsal view; 13 - detail of wing base, dorsal view. cst sp - costal spinule. Scale: $0.1 \mathrm{~mm}$.

\section{KEY TO EOTHALASSIUS SPECIES}

1 Discal cell absent (crossvein dm-cu absent). Wing moderately broad, 3.0 times longer than wide. 6-7 dorsocentral bristles of different length present. Acrostichal bristles minute. Male: palpus truncate apically.... E. platypalpus sp. n.

- Discal cell present (crossvein dm-cu present). Wing very narrow, 4.0 times longer than wide. 3 dorsocentral bristles of subequal length present. Acrostichal bristles absent. Male: palpus pointed apically........ E. gracilis sp. n.

\section{Eothalassius platypalpus sp. n.}

(Figs 1-21)

A very small, rather robust species (1.0-1.2 mm long); postpedicel broad ovate, style nearly 8.0 times as long as postpedicel; palpus truncate, white in male and brownish yellow in female; wing about 3.0 times longer than broad, without discal cell (crossvein dm-cu absent).

Male

Head (Figs 1, 2) light brown in ground-colour, lacking prominent pruinosity, subshining; upper median part of occiput strongly concave. Frontal-orbital, anterior ocellar, vertical and some upper postocular bristles dark, otherwise head with pale setation. Postocular occipital bristles minute, arranged mostly in 2-3 irregular rows, more numerous and irregularly arranged in lower part. Antenna (Fig. 5), including style, yellow (sometimes with brownish tinge or style yellowish brown in darker specimens). Postpedicel broad oval, nearly 2.0 times broader than long. Style about 8.0 times as long as postpedicel. Proboscis pale. Palpus (Fig. 6) pale yellow in groundcolour, clothed in dense pale appressed setae intermixed with scattered erect setulae (palpus silvery white in some angle of view), almost entirely flattened (except extreme base), dilated toward apex, truncate apically, somewhat longer than proboscis. Mouthparts as in Figs 7-9.

Thorax (Fig. 10) paler than head, largely pale brownish yellow in ground-colour, subshining, without prominent pruinosity; sutures brown to varying extent. Prosternum (Fig. 11) fused with proepisternum but with traces of sutures between them visible anteriorly and pos- 

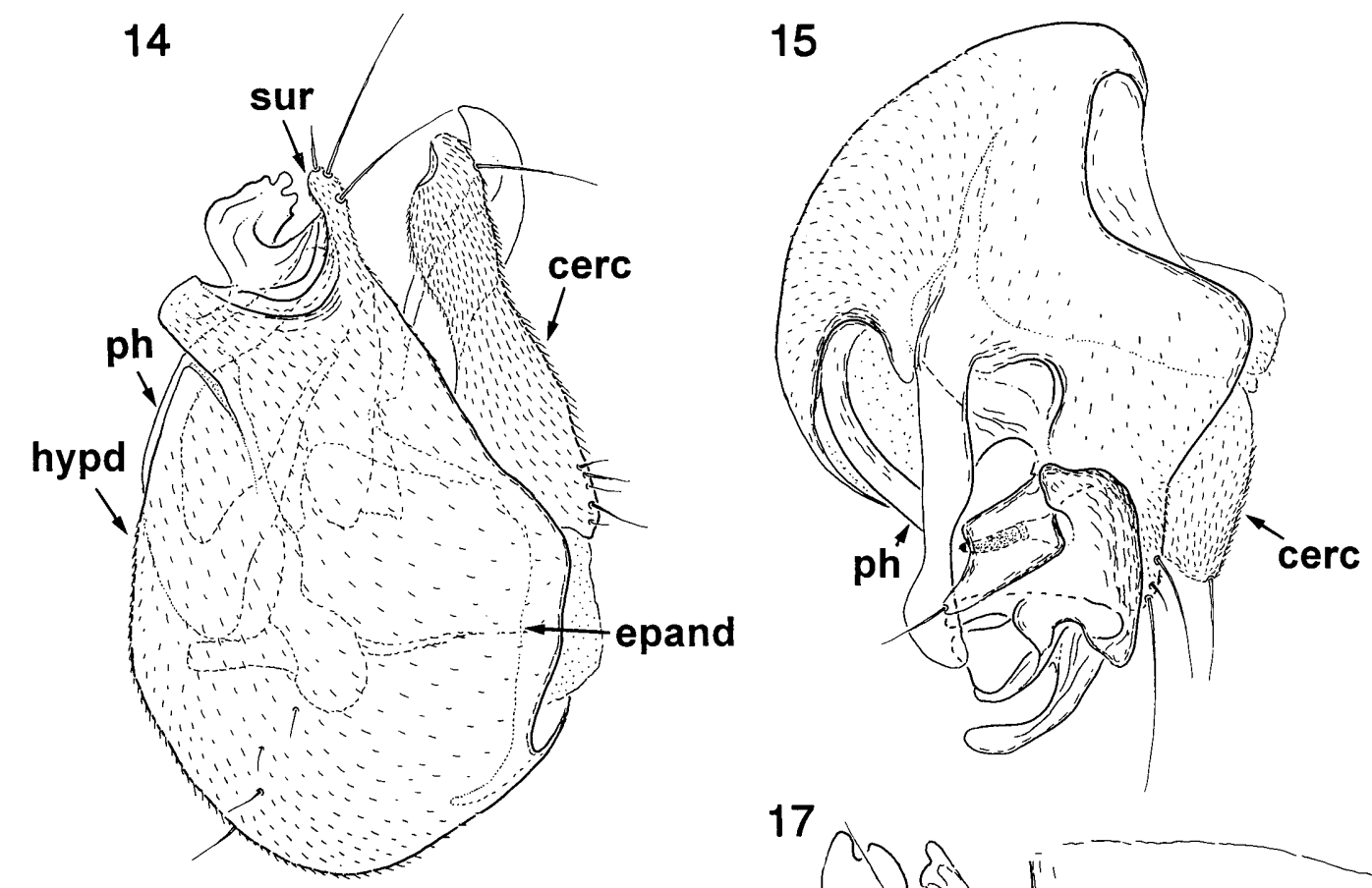

16
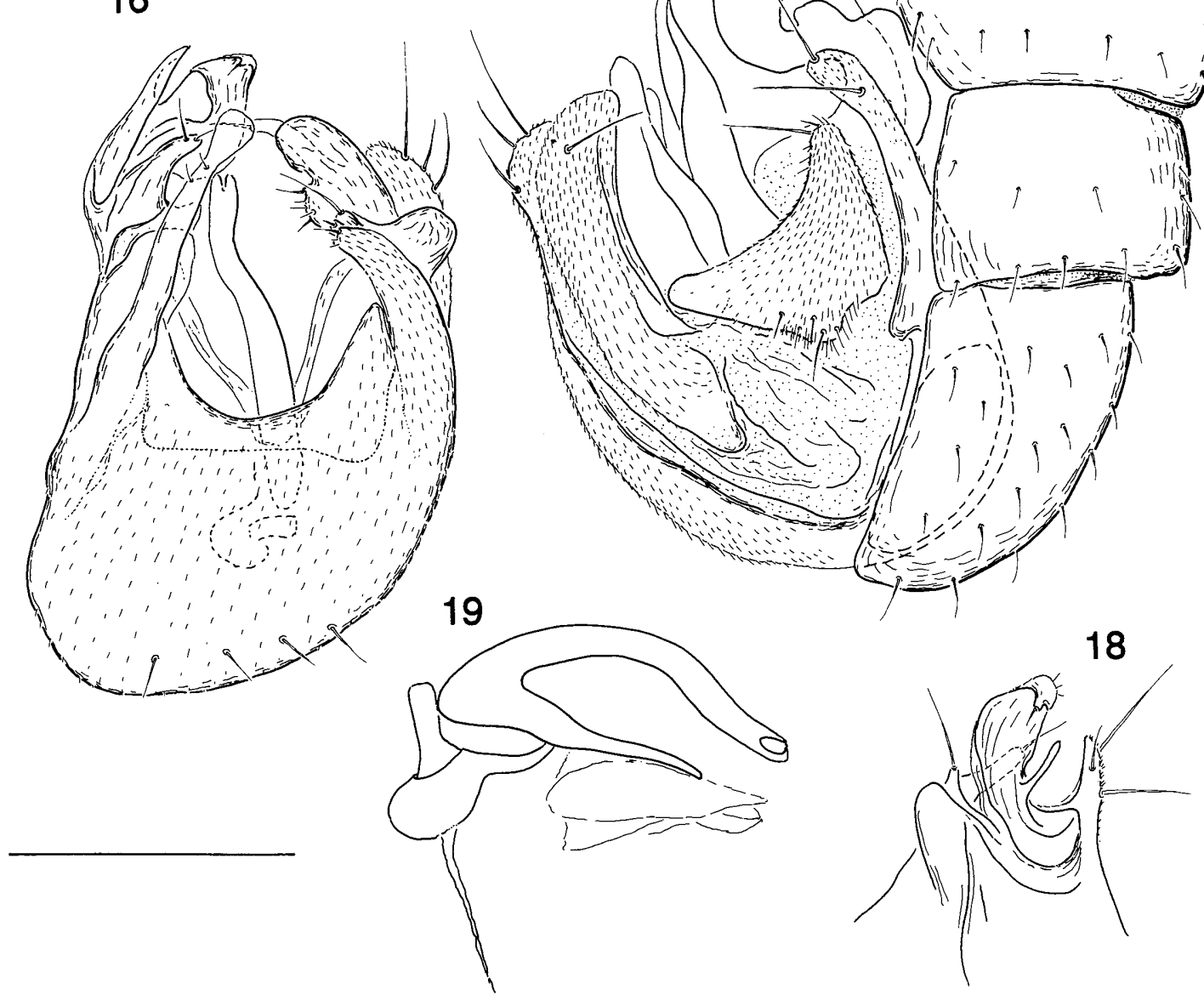

Figs 14-19. Eothalassius platypalpus sp. n. 14 - male terminalia, right lateral view; 15 - the same, left lateral view; 16 - the same, dorsal view; 17 - the same, ventral view; 18 - apical part of right epandrial lamella, dorsolateral view; 19 - phallus, lateral view. cerc - cercus; epand - epandrium; hypd - hypandrium; ph - phallus; sur - surstylus. Scale: $0.1 \mathrm{~mm}$.

teriorly. Scutum with traces of 3 darkened vittae (viewed dorsally) on lines of acrostichal and dorsocentral bristles and with similar darkening on prescutellar space and above notopleural depression. Main thoracic bristles dark, setulae pale. Dorsocentrals irregularly 1-serial, about 6-7 per row, of different length (one pair of prescutellars 

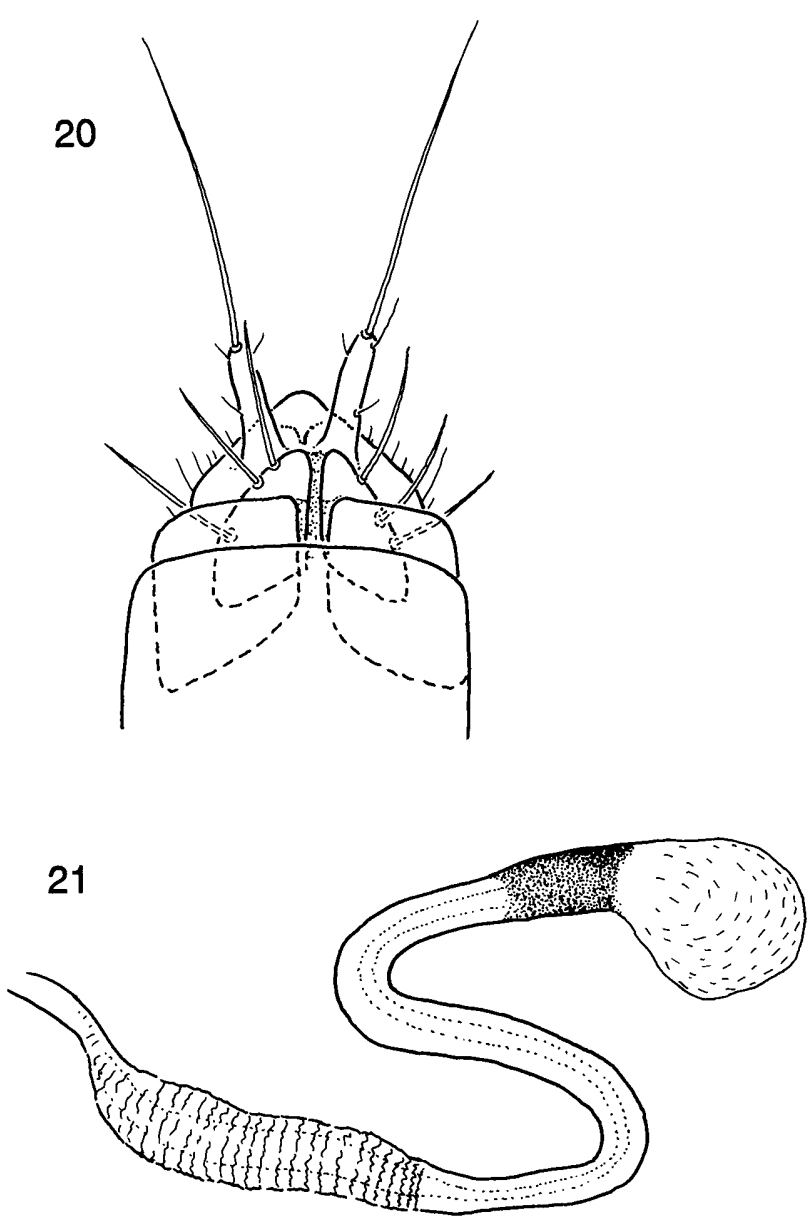

Figs 20, 21. Eothalassius platypalpus sp. n. 20 - female oviscapt, dorsal view; 21 - spermatheca, dorsal view. Scale: 0.1 $\mathrm{mm}$.

longest), with some additional setulae in middle part and one pair of long bristles situated anteriorly aside of other dorsocentral setae. Acrostichals minute, few in number, present in anterior part of scutum only, arranged in two irregular rows. Thoracic spiracles pale.

Legs largely yellow including coxae, tarsomeres 4-5 and hind femur in apical part with slight brownish tinge (in darker specimens all tarsi, hind femur in apical part and hind tibia basally with slight brownish tinge), subshining, with pale inconspicuous setation. Femora somewhat broader than corresponding tibiae, more or less gradually tapering toward apex, subequal in thickness. Tibiae and tarsi slender; tarsomere 1 distinctly longer than tarsomere 2, but somewhat shorter than tarsomeres 2-5 combined; tarsomeres $2-5$ of subequal length. Fore coxae with few long setae in apical part and some setulae anteriorly; mid and hind coxae with 2-3 long setae on outer side. Trochanters with few minute setulae. Fore femora with one row of postero- and one row of anteroventral setae becoming longer toward base of femur; mid and hind femora with 1 row of anteroventral setae becoming longer toward apex of femur; additionally, some prominent short setae present on all femora near apex dorsally and hind femur with few erect setae near base; longest bristles on femora at most half as long as width of corre- sponding femur; otherwise femora clothed in ordinary setulae. Fore tibiae with anterior apical comb and one short spine-like ventral preapical seta; mid tibiae with several setae around apex, including one longest ventral preapical one; hind tibiae with posterior apical comb and one ventral apical spine. Tarsomeres 1-4 with ventral minute spinules; hind tarsomere 1 with posterior apical comb and one short ventroapical spine; tarsomere 5 somewhat flattened dorsoventrally. Tarsal claw shorter than apical width of tarsomere 5; pulvilli short, broad; empodium slender, with ventral pubescence.

Wing (Figs 12, 13) about 3.0 times longer than wide, hyaline to very finely infuscate, with yellowish to brownish yellow (in darker specimens) veins, white marginal fringe, yellow basicostal setae and black costal spinules. Cell dm absent (crossvein dm-cu absent). Squamae pale, almost bare, with scattered pale minute ciliae. Halter pale.

Abdomen short and broad, subshining, without prominent pruinosity; with scattered very short setae, sternite 8 with more numerous and longer setae (especially on hind margin). Tergites 1-5 largely brownish yellow, pale laterally and posteriorly, tergites 6-8 brownish yellow; sternites $1-5$ pale (except brownish yellow tubercles on sternite 5), sternites 6-7 brownish yellow; marginal sclerotisation of pregenital segments brownish, visible (viewed laterally) as a contrasted narrow stripe.

Terminalia (Figs 14-19). Hypandrium and epandrium brownish yellow, processes pale yellow. Hypandrium bearing 4-5 short bristles arranged in one more or less regular transverse row (number, length and position of bristles varying) in basal part. Epandrium with left ventral projection long, mostly slender, somewhat broadened and bearing 2-3 short bristles in apical part; right ventral projection short, broad. Surstyli with outer process rather short, broad, bearing two long and one short bristles. Cerci white; right cercus long, narrow, subrectangular, with more or less rounded apex, covered with microtrichia, bearing one long bristle on inner margin and several bristles of different length basally; left cercus rather trapezium-like, with concave anterior margin, clothed in microtrichia, with one long bristle on anterior margin and several shorter ones basally. Phallus as in Fig. 19.

Length. Body $1.0-1.1 \mathrm{~mm}$, wing 0.9-1.0 mm.

\section{Female}

Similar to male except for the following characters. Head as in Figs 3, 4. Palpus brownish yellow, somewhat shorter than proboscis, less flattened, with ordinary setulae. Oviscapt as in Fig. 20. Spermatheca (Fig. 21) with receptacle finely pigmented, base of spermathecal duct, nearest to receptacle strongly pigmented, remaining duct unpigmented, apical part of spermathecal duct with tracheae-like surface.

Length. Body 1.1-1.2 mm, wing 1.0-1.1 mm.

Type material. Holotype, $\hat{\jmath}$, PAPUA NEW GUINEA: Madang province, Rivo, along creek, sample $\mathrm{n}^{\circ}$ 87145, 7.ix.1987, P. Grootaert (RBINS). Paratypes: $10 \delta^{\hat{*}, 2} \stackrel{9}{\text {, PAPUA }}$ NEW GUINEA: Madang, beach, sample ${ }^{\circ}$ 87145, 11.viii.1987, P. Grootaert; 10 $\widehat{0}$ PAPUA NEW GUINEA: New Ireland, 


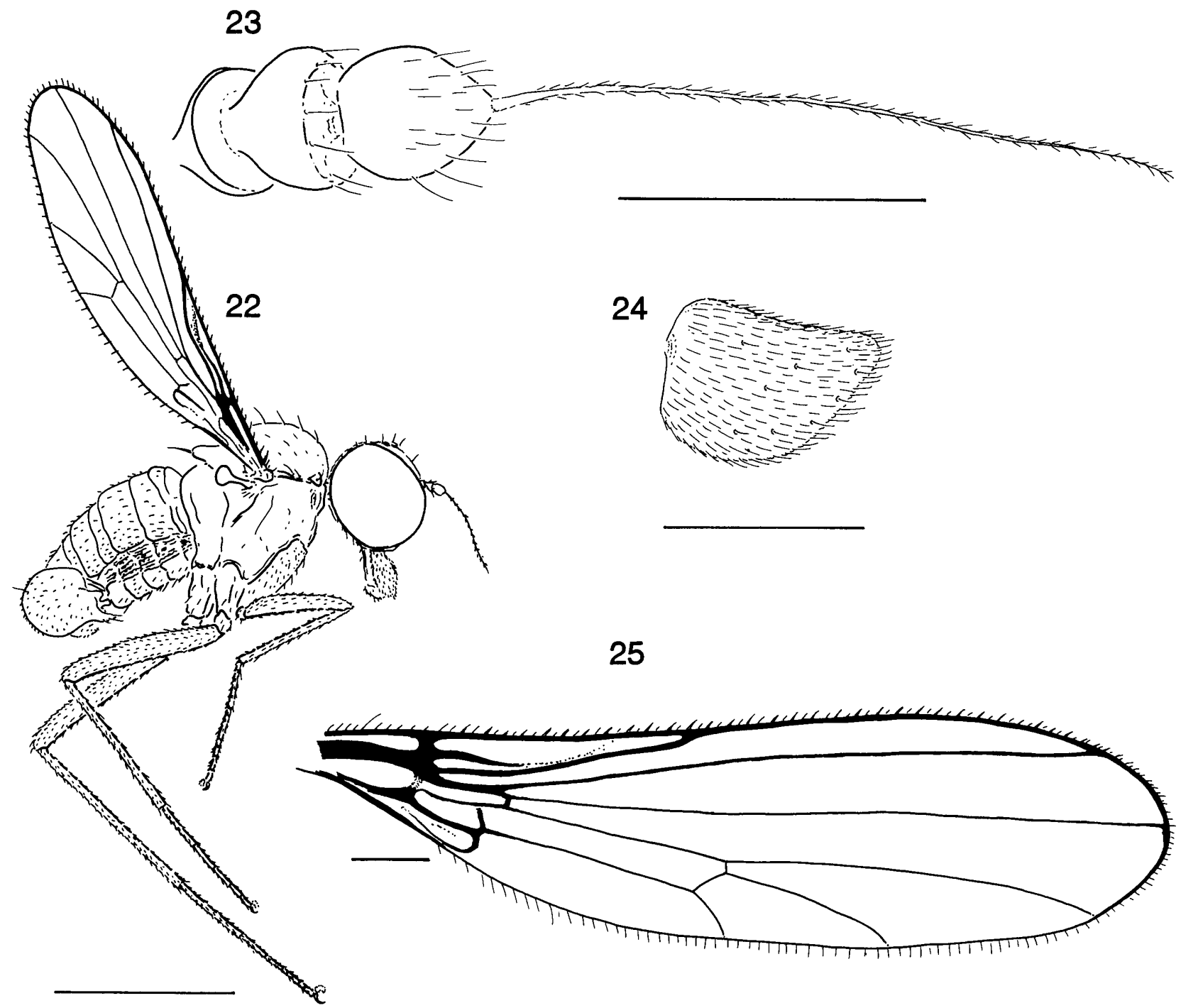

Figs 22-25. Eothalassius gracilis sp. n. 22 - male habitus, left lateral view; 23 - male antenna, dorsal view; 24 - male palpus, dorsal view; 25 - wing, dorsal view. Scales: $22-0.5,23-25-0.1 \mathrm{~mm}$.

Taskiki, sandy beach along creek, sample n 93075, 28.iv.1993, P. Grootaert (RBINS).

Etymology. The specific name is in reference to the very large and flattened male palpus.

Distribution. Papua New Guinea.

Differential diagnosis. E. platypalpus sp. n. can be readily distinguished from the second species of the genus described below as it has been given in the key.

Remarks. E. platypalpus sp. n. is one of the smallest species among Empidoidea. Its body size could be compared with that of some species of Stilpon Loew, 1859 (Tachydromiinae) and, especially, with the so-called "microdolichopodids" (e.g. Enlinia Aldrich, 1933; Cryptopygiella Robinson, 1975; Babindella Bickel, 1987). The new species is currently known from a few localities in Papua New Guinea. However, it has long seasonal occurrence and is likely to have wider distribution.

\section{Eothalassius gracilis sp. $\mathbf{n}$.}

(Figs 22-29)
A small slender species (1.2-1.4 mm long), for habitus see Fig. 22; postpedicel short ovate, style nearly 5.0 times as long as postpedicel; palpus pointed and white in male; wing very narrow, 4.0 times longer than wide, with discal cell (crossvein dm-cu present).

Male

Head dark brown in ground-colour, with fine pruinosity (probably denser on face), subshining; frons with bluish violet tinge (viewed anteriorly); upper median part of occiput moderately concave. Large bristles of head yellow, setulae pale. Postocular occipital bristles short, arranged mostly in one regular row, becoming 2-serial in lower part. Antenna (Fig. 23) with scape, pedicel and postpedicel yellow, with fine brownish tinge; postpedicel short oval, nearly 1.5 times longer than broad; style yellowish brown, about 5.0 times as long as postpedicel. Palpus (Fig. 24) subtriangular, tapered toward apex, pointed at tip, subequal in length to proboscis.

Thorax yellowish brown in ground-colour. Scutum (viewed dorsally) unicolorous. Main thoracic bristles 

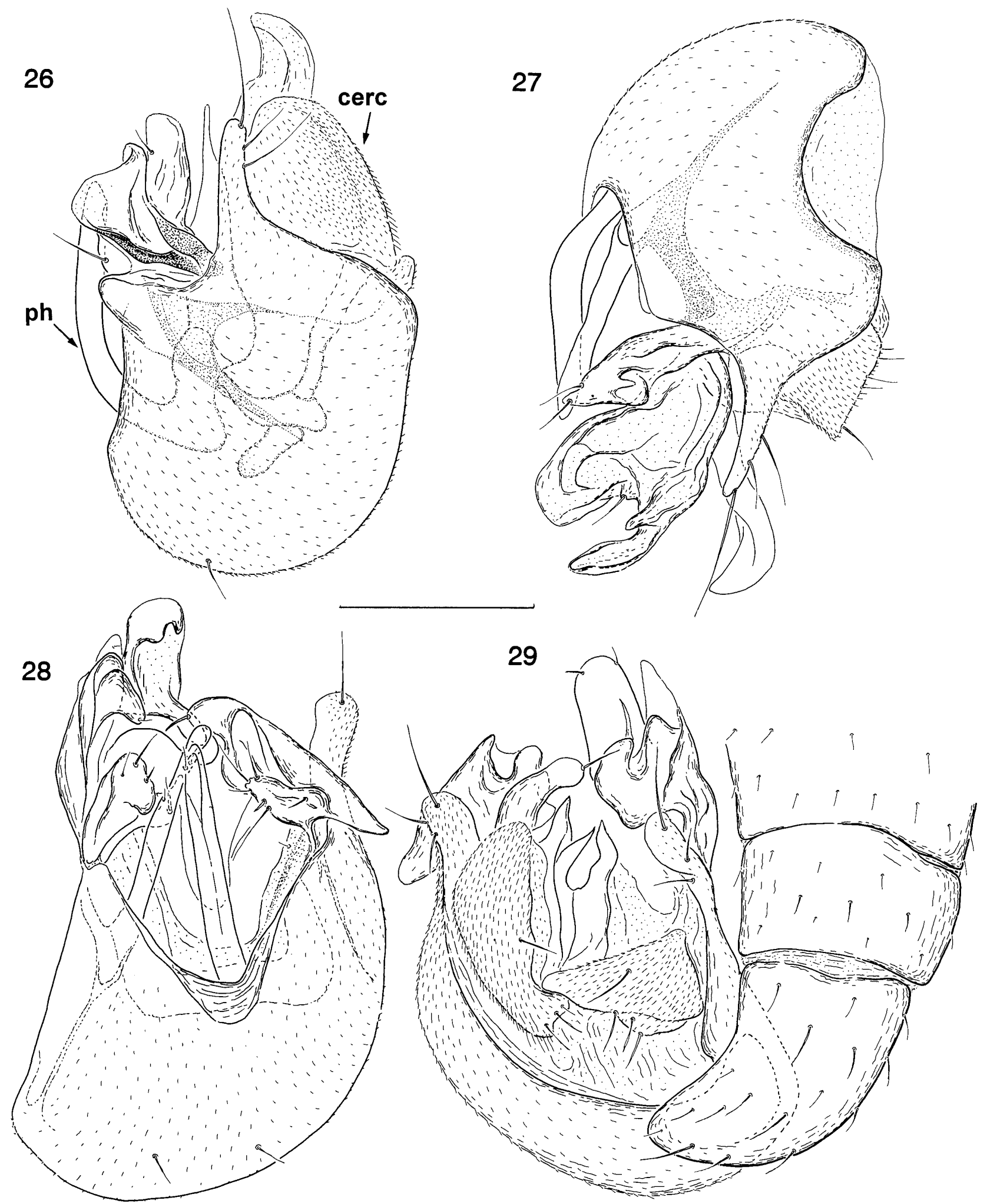

Figs 26-29. Eothalassius gracilis sp. n. 26 - male terminalia, right lateral view; 27 - the same, left lateral view; 28 - the same, dorsal view; 29 - the same, ventral view. cerc - cercus; ph - phallus. Scale: $0.1 \mathrm{~mm}$.

brownish yellow to yellow. Dorsocentrals 1-serial, three per row, long, of subequal length (including prescutellars), without accessory setulae. Acrostichals lacking.
Legs long, slender, almost entirely yellow including coxae (knees and tarsomeres 4-5 with slight brownish tinge), with yellow to pale setation, tarsal claws dark. Tarsomeres gradually becoming longer (from 1st to 4th), tarsomere 1 distinctly longer than tarsomere 2 but some- 
what shorter than tarsomeres 2-5 combined; tarsomeres 4-5 of subequal length. Fore coxa with row of short setae anteriorly. Fore femur with one row of postero- and one row of anteroventral setae becoming longer toward base of femur (longest setae scarcely shorter than femur is wide at base); mid and hind femora with one row of very short anteroventral setae; additionally, some prominent short setae present on all femora anteriorly and near apex dorsally.

Wing (Fig. 25) about 4.0 times longer than wide, finely infuscate, somewhat deeper along anterior margin; with largely yellowish brown veins (paler basally), pale marginal fringe, brownish yellow basicostal bristles and brownish costal spines. Cell dm present (crossvein $\mathrm{dm}-\mathrm{cu}$ present), long, very narrow, about 6.0 times longer than broad, anterior portion of crossvein m-cu (base of vein $\mathrm{M}_{2}$ ) very short, thin. Squamae pale, almost bare, with scattered pale minute ciliae. Halter white.

Abdomen. Tergites largely light brown, tergites 1-2 pale laterally and posteriorly; sternites largely pale brown, sternites 6-8 somewhat darker.

Terminalia (Figs 26-29). Hypandrium and epandrium pale brown, including visible processes. Hypandrium bearing two short bristles in basal part. Epandrium with left ventral projection long, slender, somewhat tapered, bearing 2-3 short bristles in apical part. Surstyli with outer process rather long, slender, bearing two long and one shorter bristles. Cerci yellow, with slight brownish tinge; right cercus rather broad ovate, covered with microtrichia, bearing one long bristle on inner margin and several bristles of different length basally; left cercus triangular, clothed with microtrichia, bearing one long bristle nearer to anterior margin and several bristles of different length on posterior margin in middle. Phallus evenly arcuate. Otherwise as in E. platypalpus.

Length. Body 1.2-1.4 mm, wing 1.0-1.1 mm.

Female

Similar to male except for the following characters. Palpus brownish yellow, with ordinary setulae. Wing somewhat broader. Postabdomen as in E. platypalpus. Cercus brownish yellow. Spermatheca not examined.

Length. Body 1.2-1.3 mm, wing 1.1-1.2 mm.

Type material. Holotype, $\widehat{\delta}$, THAILAND, Nangtong (Phang-Nga province), Khao Lak, eulitoral and supralitoral of sandy beach, 9.iv.1996, P. Grootaert (RBINS). Paratypes, 10 , 1 ㅇ PAPUA NEW GUINEA, Laing I, sample no. 94059, 6.iv.1994, P. Grootaert; 10 , INDONESIA, Irian Jaya, Sanoba beach (Nabire), sample no. 970021, 21.iv.1997, P. Grootaert; 10 , PAPUA NEW GUINEA, Laing I. (Madang prov.), white water traps, st. XXII, 2.-4.iii.1992, P. Grootaert; 10, 1 , INDONESIA, Sumatra, Pulau Sirandah, sample no. 94015, 24.iii.1994, P. Grootaert (RBINS).

Etymology. The specific name is in reference to the general habitus of the body.

Distribution. Thailand, Indonesia, Papua New Guinea.

Differential diagnosis. E. gracilis sp. n. differs from $E$. platypalpus sp. n. by a number of distinctive characters given in the key.
Remarks. E. gracilis sp. n. is rather widely distributed. It was only collected on eulitoral and supralitoral zones of sandy beaches. Some specimens taken from Papua New Guinea are scarcely smaller and paler, which may be attributed to intraspecific variability. Additionally, 10 and 1 (Papua New Guinea, Laing I, 6.iv.1994, 94059) have an aberrant venation of their right wing, where discal cell is absent (crossvein m-cu absent).

\section{DISCUSSION}

Cumming \& Brooks (2002) have recently performed a cladistic analysis of the relationships within the Microphorinae (with the tribe Parathalassiini) + Dolichopodidae lineage of Empidoidea, including all fossil and extant genera of the former. An attempt to include Eothalassius in these author's data matrix (21 characters) indicates that the relationships for the new genus cannot precisely be established at present despite inclusion in the presumably paraphyletic tribe (or subfamily by authors) Parathalassiini. Within Parathalassiinae, as this group is currently defined, Eothalassius belongs to the clade including all extant genera and Electrophorella (Cumming \& Brooks, 2002: Figs 14-16). The new genus has the female tergite 10 with acanthophorous setae that could be interpreted as an indication of the closer relationship of Eothalassius with Thalassophorus, Amphithalassius and Plesiothalassius. However, this appears to be a highly homoplasious character state within Microphorinae and Parathalassiinae (Shamshev, 2003; Shamshev \& Grootaert, 2004).

Eothalassius possesses two unique features of the mouthparts and the male terminalia, which are absent in other genera assigned to the Parathalassiinae.

In these groups (as well as in Microphor and Schistostoma), the epipharynx is a uniform elongate sclerite whereas in Eothalassius it has a slender projection. This feature is a well-known characteristic of the mouthparts of Dolichopodidae where it shows a great variability. Satô (1991) hypothesised that the mouthparts of Dolichopodidae (as predators of small invertebrates) have probably evolved towards the development of the epipharyngeal projections, a wide space between labella, and sclerotisation of pseudotracheae. The epipharyngeal projections appear to be used for tearing the prey. The two latter features deal with the necessity of keeping the prey in the oral cavity. Unfortunately, nothing is known about feeding habits in Parathalassiinae. They are considered to be predators but direct observations are needed. Nevertheless, following the idea noted, the structure of the epipharynx of Eothalassius agrees quite well with that presumed as an ancestral state for Dolichopodidae. The same may be attributed to the pseudotracheae, which in Eothalassius are weakly sclerotised. But the labella are very peculiar, being produced into an apical lobe that is a unique feature of the new genus.

In Eothalassius hypandrium and epandrium of the male terminalia are almost entirely fused. This may be similar to that in the Dolichopodidae where the genital capsule is considered to be a complex structure consisting of fused elements of epandrium and hypandrium (Ulrich, 1974, 
1976; McAlpine, 1981). In Microphorinae + Parathalassiinae the plesiomorphous state of the male hypopygium is characterised by the epandrium being well separated from the hypandrium (Hennig, 1976; Chvála, 1983; Ulrich, 1988). The hypopygium of Dolichopodidae are further apomorphous in the presence of a foramen located usually on the left lateral side, the hypandrium being prolonged at apex forming a protective cover for the phallus and some other features (Ulrich, 1974; Bickel, 1987).

In addition to the characters discussed, Eothalassius differs from all Parathalassiinae by the shortened vein $\mathrm{R}_{1}$ ending before the midpoint of the wing. However, this character is present in Avenaphora Grimaldi and Cumming, 1999 that was described recently from Lebanon amber (Grimaldi \& Cumming, 1999) and in Retinitus known from the Upper Cretaceous of Siberia (Negrobov, 1978). It is interesting to note that, like Avenaphora, E. platypalpus has no discal cell (crossvein dm-cu, or posterior portion of m-cu, absent). But Avenaphora differs primarily from Eothalassius by the 2-articulated style and the bare eyes. The discal cell is also absent in Retinitus (crossvein m-cu completely absent) and Electrophorella (anterior portion of crossvein m-cu absent).

To conclude, our paper demonstrates that recent Parathalassiinae are poorly known and many new taxa are likely to be yet undescribed. Resolution of the precise relationships between Microphorinae, Parathalassiinae and the traditional Dolichopodidae requires a special detailed study. This lineage of Empidoidea is relatively well represented in Cretaceous amber (Grimaldi \& Cumming, 1999). However, our knowledge of the fossil representatives of these groups is still insufficient. The basal relationships within the traditional limits of the Dolichopodidae remain unclear (Cumming \& Brooks, 2002). Additionally, many important morphological characters, especially from the male terminalia, have not been studied in detail in some genera of Parathalassiinae.

When the manuscript of this paper had been sent to the journal, we received a reprint of the paper published by Gatt (2003). It describes two new species of Microphorella from the Mediterranean. One of these species, namely $M$. merzi Gatt, 2003, is strikingly similar to $E$. platypalpus sp. n. described here and, thus, could also be likely to be ascribed to the newly established genus. The systematic position of this species should be clarified in the future.

ACKNOWLEDGEMENTS. This study was supported by the Belgian Federal Services for Scientific, Technical and Cultural Affairs. The second author (P.G.) thanks to P. Ng and D. Yeo of National University of Singapore for the grant and their help to obtain the research permits. P.G. also acknowledges the help of Singapore National Parks. Further P.G. also thanks the authorities of Srinakharinwirot University for the help in obtaining a Thai research permit.

\section{REFERENCES}

BICKEL D.J. 1987: Babindellinae, a new subfamily of Dolichopodidae (Diptera) from Australia, with a discussion of symmetry in the dipteran male postabdomen. Entomol. Scand. 18: 97-103.
Chvála M. 1981: Classification and phylogeny of Empididae, with a presumed origin of Dolichopodidae (Diptera). Entomol. Scand. (Suppl.) 15: 225-236.

Chvála M. 1983: The Empidoidea (Diptera) of Fennoscandia and Denmark. II. General part. The families Hybotidae, Atelestidae and Microphoridae. Fauna Entomologica Scandinavica 12. Scandinavian Science Press, Klampenborg, 279 pp.

ChVÁla M. 1988: Revision of Palaearctic Microphoridae (Diptera). 3. Parathalassiinae (Parathalassius Mik and Microphorella Becker). Acta Entomol. Bohemoslov. 85: 352-372.

Colless D.H. 1963: An Australian species of Microphorella (Diptera: Empididae), with notes on the phylogenetic significance of the genus. Proc. Linn. Soc. N. S. W. 88: 320-323.

Collins K.P. \& Wiegmann B.M. 2002: Phylogenetic relationships and placement of the Empidoidea (Diptera: Brachycera) based on $28 \mathrm{~S}$ rDNA and EF-1 $\alpha$ sequences. Insect Syst. Evol. 33: $421-444$.

Cumming J.M. \& BRooks S.E. 2002: Electrophorella, a new genus of parathalassiine flies from Baltic amber, with a cladistic analysis of the Microphorinae + Dolichopodidae lineage (Diptera: Empidoidea). Stud. Dipterol. 9: 41-54.

Cumming J.M. \& Sinclair B.J. 2000: A new phylogenetic classification of the Empidoidea. Abstract Book, 21st International Congress of Entomology (Brazil, Foz do Iguassu). Vol. 1. p. 924.

Evenhuis N.L. 1994: Catalogue of the Fossil Flies of the World (Insecta: Diptera). Backhuys Publishers, Leiden, $600 \mathrm{pp}$.

GatT P. 2003: New species and records of Microphorella Becker (Diptera: Empidoidea, Dolichopodidae) from the Mediterranean region. Rev. Suisse Zool. 110: 669-684.

Grimaldi D.A. \& Cumming J.M. 1999: Brachyceran Diptera in Cretaceous ambers and Mesozoic diversification of the Eremoneura. Bull. Am. Mus. Nat. Hist. 239: 1-124.

HeNNIG W. 1970: Insektenfossilien aus der Unteren Kreide. II. Empididae (Diptera, Brachycera). Stutt. Beitr. Naturk. (A) No. 214, $12 \mathrm{pp}$.

HeNNIG W. 1971: Insektenfossilien aus der Unteren Kreide. III. Empidiformia ("Microphorinae") aus der unteren Kreide und aus dem Baltischen Bernstein; ein Vertreter der Cyclorrhapha aus der unteren Kreide. Stutt. Beitr. Naturk. (A) No. 232, 28 pp.

HenNIG W. 1976: Das Hypopygium von Lonchoptera lutea Panzer und die phylogenetischen Verwandtschaftsbeziehungen der Cyclorrhapha (Diptera). Stutt. Beitr. Naturk. (A) No. 283, 63 pp.

McAlpine J.F. 1981: Morphology and terminology - adults. [Chapter] 2. In McAlpine J.F., Peterson B.V., Shewell G.E., Teskey H.J., Vockeroth J.R. \& Wood D.M. (eds): Manual of Nearctic Diptera. Vol. 1. Agriculture Canada Monograph 27, Ottawa, pp. 9-63.

Melander A.L. 1928: Diptera, Fam. Empididae. In Wytsman P. (ed.): Genera Insectorum. Vol. 185. Louis Desmet-Verteneuil, Bruxelles, $434 \mathrm{pp}$.

Negrobov O.P. 1978: Flies of the superfamily Empidoidea (Diptera) from Cretaceous retinite in Northern Siberia. Paleontol. Zh. 12(2): 81-90 [in Russian, English translation in: Paleontol. J. 1978(2): 221-228. Washington].

Pollet M. \& Grootaert P. 1987: Ecological data on Dolichopodidae (Diptera) from a woodland ecosystem: I. Colour preference, detailed distribution and comparison of different sampling techniques. Bull. Inst. R. Sc. Nat. Belg. (Entomol.) 57: 173-186.

Saigusa T. 1986: New genera of Empididae (Diptera) from Eastern Asia. Sieboldia 5: 97-118. 
SATô M. 1991: Comparative morphology of the mouthparts of the family Dolichopodidae (Diptera). Insecta Matsum. (N.S.) 45: 49-75.

Shamshev I.V. 1998: Two new species of the genus Parathalassius Mik (Diptera: Microphoridae) from the Russian Far East, with a key to world species. Int. J. Dipterol. Res. 9: 3-8.

Shamshev I.V. 2003: A new species of the genus Microphorella Becker from the Far East of Russia, with notes on some morphological features in the Microphorinae (Diptera: Empidoidea). Stud. Dipterol. 10: 527-535.

Shamshev I.V. \& Grootaert P. 2003: A new genus of Microphorinae (Diptera, Empidoidea) from New Zealand. Belg. J. Entomol. 4[2002]: 129-144.

Shamshev I.V. \& Grootaert P. 2004. Descriptions of four new species of the genus Microphorella Becker (Diptera: Empidoidea, Parathalassiini) from Southern Asia and New Guinea, with notes on the relationships within the genus. Raffles Bull. Zool. 52: 45-58.

Sinclair B.J. 2000: Morphology and terminology of Diptera male terminalia. In Papp L. \& Darvas B. (eds): Contributions to a Manual of Palaearctic Diptera 1. Science Herald, Budapest, pp. 53-74.

SмIтH K.G.V. 1972: A remarkable new Parathalassius (Diptera: Empididae) from South Africa, with a key to world species. Ann. Nat. Mus. 21: 455-458.
Stuckenberg B.R. 1999: Antennal evolution in the Brachycera (Diptera), with a reassessment of terminology relating to the flagellum. Stud. Dipterol. 6: 33-48.

Ulrich H. 1974: Das Hypopygium der Dolichopodiden (Diptera): Homologie und Grundplanmerkmale. Bonn. Zool. Monogr. 5: 1-60.

UlRICH H. 1976: Morphology of the Dolichopodid hypopygium and its significance for a phylogenetic system of the family (Diptera). Unpublished paper read August 25, 1976 at the XV International Congress of Entomology, Washington, D.C.

UlRICH H. 1988: Das Hypopygium von Microphor holosericeus (Meigen) (Diptera, Empidoidea). Bonn. Zool. Beitr. 39: 179-219.

UlRICH H. 1991: Two new genera of parathalassiine-like flies from South Africa (Diptera, Empidoidea). Bonn. Zool. Beitr. 42: $187-216$.

UlRich H. 2003: How recent are the Empidoidea of Baltic amber? Stud. Dipterol. 10: 321-327.

Yeates D.K. \& Wiegmann B.M. 1999: Congruence and controversy: toward a higher-level phylogeny of Diptera. Ann. Rev. Entomol. 44: 397-428.

Received February 5, 2004; revised July 7, 2004; accepted September 21, 2004 